\title{
Article
}

\section{African journalism: A journey of failures and triumphs}

Ogola, George Otieno

Available at http://clok.uclan.ac.uk/12931/

Ogola, George Otieno ORCID: 0000-0002-4513-4550 (2015) African journalism: A journey of failures and triumphs. Ecquid Novi : African Journalism Studies, 36 (1). pp. 93-102. ISSN 2374-3670

It is advisable to refer to the publisher's version if you intend to cite from the work. http://dx.doi.org/10.1080/23743670.2015.1008175

For more information about UCLan's research in this area go to http://www.uclan.ac.uk/researchgroups/ and search for < name of research Group>.

For information about Research generally at UCLan please go to http://www.uclan.ac.uk/research/

All outputs in CLoK are protected by Intellectual Property Rights law, including Copyright law. Copyright, IPR and Moral Rights for the works on this site are retained by the individual authors and/or other copyright owners. Terms and conditions for use of this material are defined in the policies page.

\section{CLoK}

Central Lancashire online Knowledge www.clok.uclan.ac.uk 


\title{
African Journalism: A journey of failures and triumphs
}

\author{
George Ogola, University of Central Lancashire.
}

\section{Introduction}

The 1990s remain epochal in the transformation of African journalism. This period coincides with the adoption of political pluralism in many African countries, an era that was attended by the broader liberalisation of African economies. The media sector, once dominated by the state, was finally opened to private enterprise. As a consequence, both the broadcast and print media sectors have since witnessed an unprecedented expansion with numerous radio and TV stations as well as newspapers set up across the continent. Examples across the continent show staggering growth. In Kenya, from just three TV stations and handful of print media in the 1990s, by 2012 the country had 301 radio stations, 83 TV stations, 20 monthly magazines, 6 dailies and 11 regular weeklies (Status of Media Survey Report, May, 2012). In Nigeria, in the print media sector alone, there were more than 100 national and local regular newspaper titles in 2012(Mapping Digital Media: Nigeria Report, 2012). In Uganda, the radio sector saw an explosion of FM radio stations in the late 1990s and today, these can be found in some of the remotest parts of the country. While the picture might be mixed in various pockets of the continent, the phenomenal growth of the media sector in general in the continent is certainly not overstated.

The growth of the news media has meant that spaces for popular public expression have expanded considerably. As such, African journalism has become increasingly important and influential in the everyday lives and practices of Africans and in influencing the continent's political, economic and cultural processes. And yet this role remains fraught with tensions. In countries emerging from difficult historical experiences such as South Africa, various debates still attend the role the media that the country's journalism should play in post-apartheid South Africa. Rodny-Gumede and Ogola (2014), for example, argue that "at the top of these debates .... has been how best to transform the news media... and what role the media should play in the new democratic South Africa" (230). They observe that this particular debate has "focused on whether or not the media should privilege its watchdog role or report on the progress the government has made since the end of apartheid" (ibid). Elsewhere in the continent, in countries such as Kenya and Tanzania, the narrative has been similar. The argument has been that the media's right to criticise the state has to be counterbalanced by its 
other 'important' role of helping 'build the nation' (Ogola, 2011). More broadly, the dominant question across the continent remains whether the character of African journalism and media in general should be fundamentally developmental.

\section{Africa's media and the pains of growth}

The debate about the (re-)orientation of African journalism and media can be explained on the difficulties encountered in the various attempts to reconcile the media's assumed postindependence role of state-building, with its emergent mandate in pluralist societies of ensuring Executive probity. Additionally, we may explain it on the sometimes chaotic nature of the media liberalisation process in the continent. The process was rapid, unprecedented and on occasion failed to usher a radically different new dispensation.

Today, therefore, African journalism continues to face a number of significant challenges. While the new political order may have undermined the power of the state, particularly its direct control over the media, many governments across the continent have over the years devised new ways of frustrating the fledgling media. Across the continent are new legal regimes established to frustrate African journalists. For example, Article 19 describes the Gambia as having some of the harshest laws on the right to freedom of expression in the continent. In 2013, the country's National Assembly passed the Information and Communication (Amendment) Act targeted at online speech. The Act is deliberately ambiguous. It criminalises 'offences' such as spreading 'false news' about the government or public officials, caricaturing or making derogatory statements against public officials or 'inciting dissatisfaction' against the government. These are punishable by a fifteen-year jail term and/or a fine of USD 81000 (Article 19, 2013). In Kenya, the Kenya Information and Communications (Amendment) Bill, was just as controversial. It contains punitive provisions, which, for example, imposes hefty fines for breaches and covertly allows the Minister of Information to censor the media in the interest of 'good taste'. Even in much more liberal countries such as South Africa, there is always the threat of punitive legislation aimed at silencing journalists. Two proposed pieces of legislation in the country ostensibly aimed at safeguarding pluralism have been widely seen as stealth attempts by the government to control the media. The Protection of State Information Bill also pejoratively known as the 'Secrecy Bill', was widely seen as an attempt by the government to redefine the parameters of what constituted 'national interest' and therefore insulate the Executive from being held accountable for possible transgressions. While the version passed by Parliament was a 
watered down version of the original Bill having attracted intense public condemnation, the South African National Editors Forum (SANEF) still fears the bill "has the potential to be used as an instrument of secrecy in a democracy that can only thrive in a climate of openness" (www.sanef.org.za). Similarly, the Media Appeals Tribunal was also seen as another covert attempt at state regulation. The government argues that self-regulation has failed and is inherently incapable of protecting individual rights. Most African countries thus continue to perform poorly in the World Press Freedom Index (www.rsg.org).

The other key challenge has been the continued reliance on governments for advertising revenue. Flagging economies and a relatively small private sector in many African countries has meant that the state still remains the biggest source of advertising revenue for media. In many countries therefore, the media remains open to state manipulation and intimidation. In 2007, the Kenya government instructed all state bodies to withdraw advertisements from the local Standard newspaper, following claims by the newspaper that "a government minister had approached criminals from Armenia with a view to having former President Daniel Arap Moi's son murdered" (Reporters Without Borders, 2007). In a recent development, the same government has indicated it plans to place most of its advertising online instead of using traditional media. It is also wants them managed centrally rather than through government departments and state corporations. There has been a tradition in the country of advertising state tenders, job vacancies and notices in at least two newspapers with national circulation. The new move is likely to 'punish' particularly oppositional media. Meanwhile, in South Africa, in 2011, the head of government communications threatened to withdraw its $£ 100 \mathrm{~m}$ a year budget from newspapers which criticised the government claiming that while the government "is pro-press freedom, we can't have the press acting as proxies" either for the Opposition or for commercial interests (Johnson, 2011).

\section{African journalism and the enemy within}

While African journalism has navigated most of these challenges in pursuit of its normative roles, the quality of the journalism in some of the emergent media outfits in the continent has however been the subject of much debate and criticism. Across the continent, African media has come under criticism for its apparent failure to reconcile these new rights post-1990 with accountable journalism (Tettey, 2006). Scholars like Nyamjoh (2005) and Berger (1998) argue that while the media has indeed played a positive role in their attempt to help 
institutionalise democracy in the continent, they have themselves failed to operationalize their own accountability.

The expansion of the media in the continent has not been attended either by the appropriate legislative infrastructure or by the requisite training opportunities for journalists. As a consequence, rogue practices and rogue media are commonplace. In Kenya, for example, the exponential growth of the media particularly in the 1990s saw the emergence of the so-called 'gutter press', publications that were often funded by politicians to malign their adversaries, ruin reputations or settle scores. Most of these publications did not have permanent addresses and would appear and disappear as at when they were needed. The gutter press was soon followed by the emergence of local-language FM radios across the country. The success of one such station Kameme FM, led to the establishment of similar stations across the country, targeting most of Kenya's 42 ethnic communities. The sector's remarkable fast growth had serious implications on the quality of radio journalism in the country. In a country deeply fractured along ethno-political lines, local language radio stations quickly became conduits for the propagation of partisan ethno-political interests, often unattended by relevant legal and professional regulations or ethics. In the disputed 2007-8 presidential elections, for example, these stations were accused of actively participating in broadcasting messages that animated existing ethnic and political tensions thus contributing the conflagration that later consumed the country leaving hundreds dead and thousands displaced (BBC Trust, 2008 ). One such broadcaster Kass FM had one of its journalists indicted by the International Criminal Court at The Hague for committing crimes against humanity as result of his broadcasts. In Rwanda, Radio Television Libre des Mille Collines gained notoriety for being among the most prominent hate media outlet during the Rwanda genocide in which its broadcasters incited ethnic Hutus to kill fellow Tutsis (Kellow and Steeves, 2008)

Meanwhile, in the much bigger conurbations, while urban radio has expanded media choices for listeners, they too have come under criticism. Most of these urban radio stations operate primarily as entertainment music stations. Many therefore use non-professional journalists, quite often, local celebrities, with wide following to host or front shows in a bit to attract advertisements. But precisely because of their lack of training, they constantly disregard or are often unaware of the relevant professional ethics or regulations that should attend their broadcasts. 
Another of the significant challenges facing African journalism is the failure to fundamentally reform the ownership structures of media operations in various countries. Media concentration continues to undermine media diversity in the continent. In South Africa, while there has been a visible effort to diversify media ownership in the country since the end of apartheid, a lot has remained the same. Many have complained about the nature of the liberalisation process, which seems to have instead created even bigger and more powerful and yet, fewer media organisations. Many argue that cross-media ownership makes it impossible particularly for new players to compete with the more established players (Berger, 2001). Two companies continue to dominate South Africa's print media Independent newspapers and Media 24, which together control approximately two-thirds of the market (All Media Product Survey, 2012).

Rodny-Gumede and Ogola (2014) argue that while profitable to companies, the concentration of ownership is now increasingly constraining the country's journalism. They cite the example of Independent newspapers where newsrooms have been downsized while syndication and repurposing of stories actively encouraged in a bid to cut costs. This has led to the homogenisation of news across the groups' newspaper titles, which ultimately undermines news diversity.

In Kenya, the Nation Media Group and the Standard Group continue to dominate the country's media sector. Together, they control nearly $90 \%$ of the print media market. While there are a number of new entrants in the broadcast sector, cross-media ownership still gives the two organisation competitive advantage over the others (Studies of Media Survey Report, 2012).

\section{Addressing the challenges}

Despite the many difficulties facing African journalism, some African countries are slowly addressing these challenges. While it is true that the legislative regimes within which the continent's media operates remain inimical to media freedom, it is also true that several progressive laws have been passed to remedy the situation. There is now a formal recognition of the independence of the media in many African countries' constitutions. A number of statutory laws have also been passed to provide a much more conducive environment for the practice of journalism. In Kenya, the Media Act 2007 established the Media Council of Kenya, the body which regulates the local media industry. Although funded by the state, it is shielded from political interference by the same Act. This has created a framework that 
allows for media self-regulation. Meanwhile, The Freedom of Information Bill although yet to be passed, is intended to make it easier for journalists top get access to information particularly from the state. In Nigeria, the Freedom of Information Act was passed in 2011 (Mapping Digital Media: Nigeria Report, 2012).

Other initiatives include the increasing professionalization of the media sector. Tettey (2006) argues that in response to the criticism relating to the quality of its journalism, "various media organisations are now initiating measures to address the shortcomings of their profession" (230). In South Africa, SANEF has conducted various studies aimed at establishing problem areas in the country's newsrooms and are said to be working closely with media organisations to remedy the situation (Steyn and deBeer, 2002; Mtwana and Bird, 2006). In Kenya, all the major news organisations are now signed up to the codes of conduct written jointly by the Kenya Union of Journalists and the Media Council of Kenya. The number of journalism schools has also increased, with 23 recognised institutions including six universities offering standardised journalism training courses (Ogola and Rodny-Gumede, 2014). Further, practicing journalists now have formal representation in bodies such as the KUJ, Kenya Correspondents Association, AMWIK and many others. These organisations not only work on the improvement of working conditions of their members, they also organise workshops targeted at improving the journalistic skills of their members (ibid.).

The media, civil society and the public have also become increasingly conscious about the various attempts by governments to narrow the parameters of press freedom and individual liberties. Collectively, they have been very vocal in opposing a number of proposed legislation deemed retrogressive. Such opposition have taken place in Uganda, Kenya and South Africa often attracting international attention. As a result, we have seen repressive bills shelved or amended accordingly.

\section{Going digital: New media, new spaces, new journalism(s)}

As is the case in other parts of the world, new media and new information and communication technologies are transforming journalistic practice in Africa. While the celebratory narrative with which new media and ICTs in general is often discussed, particularly as it relates to developing country contexts is often unqualified, their impact cannot altogether be ignored. But even as we acknowledge that impact, we have to acknowledge the difficulties we are likely to encounter in both conceptual and practical terms, if we attempt to divorce the old from the new in Africa. Quite rightly, Nyamjoh 
reminds us that Africans are "daily modernising the indigenous and indigenising the modern with novel outcomes" (2005:4). He further observes that "no technology seems too used to be used, just as nothing is too new to be blended with the old for even newer results" (ibid.). The way technologies are adopted and adapted in Africa is therefore irreducible to such neat categories as old and new. The 'new' in new media here does not necessarily refer to the technology but also to the novelty with which it is used.

African journalism has creatively and proactively appropriated a range of new media technologies so fundamentally that they have become an inalienable part of the continent's journalism. Journalists across the continent have integrated these technologies in their newsrooms and adapted them to their everyday practices as journalists. In Zimbabwe, Mabweazara (2011) discusses how the mobile phone has become an integral part of the country's various newsrooms. In an ethnographic study of six newsrooms, he found that the technology's "inherent properties have spawned unprecedented flexibility in the professional communicative practices of journalists" (705). For example, its portability makes it possible for work in remote areas where local transport and the communication infrastructure is still poor. As such, journalists are able to file their stories from the field using their mobile phones. He also explains how the mobile phone has facilitated a "flexible work regime in which journalists are available to their sources and colleagues while on the move" (698). He further points to the creative use of the mobile phone's SMS facility which has also made it possible for the public in Zimbabwe to send journalists and editors alerts of various newsworthy events. This has enabled what he describes as a "shift from the centralization of journalism practice to its pluralisation" (703) or what Moyo has called elsewhere as "an intersection between top-down and bottom-up communication" (Moyo, 2009: 561 cited in Mabweazara, 703). Similar impact on journalistic practices has been identified by Motilola (2014) in her ethnographic study of four Nigerian newsrooms- Punch, Vanguard, Guardian and the Independent.

African news organizations now generally have some online presence with the platform variously used as the main media outlet, as complementary to print editions of newspapers or used by radio and TV stations to stream their programmes online. Increasingly, this platform is also used to generate revenues, expand markets and receive feedback on journalistic output. Most of these online provisions are multi-media enabled hence allow for convergence of output across media organisations' various portfolio. In very significant ways, therefore 
new media technologies have helped meet some of the resource challenges that have long frustrated many journalists and media organisations across the continent. Print media organisations without TV or radio in their portfolio can now have video packages or audio clips on their websites alongside text. This is common in countries such as Uganda, Tanzania and Rwanda.

Increasingly, the continent's journalists and media audiences are also using these new platforms and technologies to assert their discursive interests and to interact much more intimately with each other and with media organisations. The possibilities the new platforms and technologies avail users make them particularly useful in fighting both overt and indirect censorial policies often instituted by repressive governments, but also in challenging the traditional and exclusionary gatekeeping processes by news organisations. In countries where the 'bounds of the expressible' is still highly constrained, either by political systems or legislation, digital media has helped puncture some of those boundaries. The online platform, for example, has enabled exiled media such as TheZimbawean, Nigeria's Saharareporters.com or indeed Eritrea's Asmarino.com to continue serving their Africabased constituencies, often focusing on issues that would most likely attract reprisals from the respective African countries.

Meanwhile, within newsrooms, social media has forced news organisations to engage much more and on new parameters with their audiences. The relationship between the audience and the journalist, as briefly noted above in the case of Zimbabwe, is no longer necessarily hierarchical. Instead, that relationship is increasingly dialogical with 'discursive' power dispersed across the two sides.

The phenomenal uptake of social media in the continent has also played a role in (re)shaping African journalism. It is a development that is being exploited by news organisations and journalists in various ways. For example, most news organisations now have social media pages, which they use to distribute their stories, construct and grow their audiences and receive feedback. The interactive elements of the online platform and social media in particular, accessible through the mobile phone ensures news organisations are able to engage their audiences not only in the process of newsmaking, but also anywhere and at any time. Twitter and Facebook, for example, have now become important deliberative spaces with just as much significance as traditional media platforms. 
It is perhaps instructive to underscore the fact that the growth in mobile phone adoption and usage in the continent has been instrumental in this regard. While statistics on teledensity and usage often vary wildly depending on the source of data, it is broadly agreeable among researchers across the social sciences that the mobile phone is now ubiquitous in Africa. Research by scholars such as De Bruijn et al (2009) that 1 in 3 Africans had access to a mobile phone by 2009 or the 2014 ITU estimates which indicate that Africa now has 629 million active mobile-cellular subscriptions or a penetration of nearly 70 per 100 inhabitants (ITU, 2014), do indicate the significance of the mobile phone in the continent. The cultural context of usage where mobile phones are generally shared among kin and kith further demonstrates the technology's dispersal (Nyamjoh, 2005).

Partly as a result of these new media technologies, Africa has also seen the emergence of new ways of 'doing' journalism and new spaces for 'alternative' journalism(s). New media not only reduces the infrastructural capital necessary for establishing small media organizations it has also radically changed the way in which media output is produced. In places such as South Africa, for example, there have been a number of fairly innovative citizen journalism experiments. These projects have attempted to re-orient their journalism to privilege 'outsider' voices rather than those of professional journalists. The results have, however, been mixed. Some of these projects such as reporter.co.za which was part of the Mail\&Guardian website and Lindaba Ziyafika which was "an adjunct to the professional journalism in South Africa's oldest Independent newspaper Grocott's Mail” and described by Dugmore and Ligaga as "an ambitious citizen journalism project that attempted to use rapidly developing cell phone capacity and ubiquity to experiment with citizen journalism in a small town" (2014: 255) only had moderate success. In Kenya, there have been small scale citizen journalism projects such as the Ghetto Mirror, The Kibera Journal and Kibera News Network (ibid.). While many such initiatives have not been successful, the experiments have been useful as part of the continent's broader search for a truly representative and participatory model that puts audiences at the heart of its journalism.

\section{Prospects}

There is little doubt that African journalism is now central to the everyday lives of the continent's citizens. It now defines the textures of their social, cultural and economic practices and structures and fundamentally shapes the continent's political processes. The 
post-1990s moment of political pluralism and economic liberalisation brought forth a new dispensation that made possible the expansion of the media sector that has since enabled African journalism to find its voice. But the process, particularly of media liberalisation, also introduced a number of challenges some of which have been successfully met, while others continue to undermine the normative role African journalism ought to play in the continent. As such, African journalism has witnessed both failures and triumphs. The adoption as well as appropriation of new media and other ICTs is opening a new frontier for the practice of journalism in the continent and redefining the relationship between journalists, the state and audiences. The dialogue that has emerged and the conversations now taking place between the three groups portend a future where audiences will increasingly become actors and not simply recipients of and in African journalism.

\section{References:}

All Media Product Survey (AMPS). 2012. Johannesburg: South African Advertising Research Foundation

Article 19. 2013 "The Gambia: New internet law furthers government crackdown on free expression". Available at: http://www.article19.org/resources.php/resource/37152/en/thegambia:--new-internet-law-furthers-government-crackdown-on-freeexpression\#sthash.rekmG7G0.dpuf Accessed 17 October 2014.

Berger, G. (2010-08-04). "Taking the ANC media tribunal at face value". Thought Leader Available at: http://www.thoughtleader.co.za/guyberger/2010/08/04/taking-the-anc-tribunalat-face-value/. Accessed 17 October 2014.

Berger, G. 2001. "De-Racialization, Democracy and Development: Transformation of the South African Media 1994-2000”. In Tomaselli, K and Dunn, H. (eds). Media, Democracy and Renewal in Southern Africa. Colorado Springs: International Academic Publishers

De Bruijn, $M$ et al. 2009. Introduction: Mobile communications and new social spaces in Africa. In De Bruijn , M, Nyamjoh, F and Brinkman I (Eds) Mobile Phones: The New Talking Drum of Everyday Life Africa. Bamenda/Leiden: African Studies Centre, 11-12. 
Dugmore, Harry and Dina Ligaga. Citizen journalism in South Africa and Kenya. The Future of Quality News Journalism: A Cross-Continental Analysis. (Eds) Peter J. Anderson, Michael Williams, George Ogola. Routledge: New York.

Johnson, R. (2011-07-31) "South African official threaten press who criticise the government". Sunday Times Available at

http://www.thesundaytimes.co.uk/sto/news/world_news/Africa/article681915.ece Accessed 17 October 2014.

Kellow, C and Steeves, H. 1998. "The role of radio in the Rwandan genocide" in Journal of Communication 48(3): 107-128

Mabweazara, H. 2011. "Between the newsroom and the pub: The mobile phone in the dynamics of everyday mainstream journalism practice in Zimbabwe" in Journalism: Theory, Practice and Criticism 12(6):692-707

Mapping Digital Media: Nigeria Report. 2012. Cambridge: Open Society Foundations. Motilola, A. 2014. "Negotiating convergence: "Alternative" journalism and institutional practices of Nigerian journalists" in Digital Journalism 2(1): 69-76.

Mtwana, N and Bird, W. 2006. Revealing Race: An analysis of the Coverage of Race and Xenophobia in the South African Print Media. Johannesburg: Media Monitoring Project.

Nyamjoh, F. 2005. Africa's Media: Democracy and the Politics of Belonging. London and Pretoria: Zed Press and Unisa

Ogola, G. 2011. "The political economy of the media in Kenya: From Kenyatta's 'nationbuilding' press to Kibaki's fragmented nation" in Africa Today 57(3):77-95

Ogola, G and Rodny-Gumede, Y. 2014. "The future of quality journ`alism and media accountability in South Africa and Kenya". In Anderson, P, Ogola, G and Williams, M (eds). The future of journalism in the developed and developing world: A cross continental analysis. London and New York: Routledge

Policy Briefing (1). 2008. The Kenyan 2007 Elections and Their Aftermath: The Role of the Media and Communication. London: BBC World Service Trust, April. 
Reporters Without Borders. 2007. "Government orders state sector to withdraw advertising from Standard Group Media". Available at: http://en.rsf.org/kenya-government-orders-statesector-to-19-04-2007,21804.html Accessed 17 October 2014.

Status of the Media in Kenya Survey Report, May 2012. Nairobi: Media Council of Kenya.

SANEF. "Sanef Press Statement Re Protection of State Information Bill”. Available at:

http://www.sanef.org.za/news/entry/Sanef_press_statement_re_Protecton_of_State_Informat on_Bill/_Accessed 17 October 2014

Steyn, E and de Beer, A. 2002. "Sanef’s "2002 South African National Journalism Skills Audit”: Final Report. South African National Editors' Forum.

Tettey, W. 2006. "The Politics of Media Accountability in Africa: An Examination of Mechanisms and Institutions.” International Communication Gazette 68(3): 229-248 